\title{
A cultura psicológica no mercado de bens de saúde mental contemporâneo
}

\author{
The psychological culture in the contemporary \\ mental health marketplace
}

\author{
Sílvio José BENELLI
}

\begin{abstract}
Resumo
Estudou-se a hipótese da cultura psicológica proposta por Castel em 1987, buscando compreender as atuais transformações no campo social e suas incidências nas áreas da saúde mental (psiquiatria, psicanálise, psicologia). O surgimento de um novo arquipélago psicológico voltado para o desenvolvimento e o aprimoramento do potencial humano visaria a uma programação infinita do ser humano na transição da sociedade disciplinar para uma sociedade de controle. Nesse panorama, a psicologia como profissão estaria superando o tratamento e a prevenção, dirigindo-se para a criação de uma sociabilidade relacional; a filosofia clínica poderia ser considerada uma modalidade terapêutica para pessoas normais, e o eneagrama e a programação neurolinguística seriam sistemas psicoterapêuticos que buscam levar o ser humano a um autodesenvolvimento global. Decifrou-se sua função estratégica quando foram situados no contexto mais amplo da atual forma de gestão dos riscos na administração de populações problemáticas.
\end{abstract}

Unitermos: Filosofia. Programação neurolinguística. Psicologia social.

\begin{abstract}
We studied the hypothesis of psychological culture proposed by Castel, 1987, by seeking to understand the current transformations in the social field and its occurrence in the areas of mental health (Psychiatry, Psychoanalysis, Psychology). The emergence of a new psychological cluster devoted to developing and improving the potential of the human being would aim towards the infinite programming of the human being, in the transition from a disciplinary society to one of control. With this perspective, psychology as a profession would be overcoming treatment and prevention, being redirected towards creating a relational sociability: Clinical Philosophy could be considered a therapeutic mode for normal people, and Enneagram and Neuro-Linguistic Programming as psychotherapeutic systems seeking to guide the human being towards global self-development. We decoded their strategic function, while they were situated in the broader context of the current form of risk management in the administration of problematic populations.
\end{abstract}

Uniterms: Philosophy. Neuro-Linguistic Programming. Social Psychology.

\section{O fenômeno da psicologização da existência humana}

O que pode significar a abundante literatura de autoajuda, esoterismo e práticas alternativas, de orientação mais psicológica ou mais espiritual, que floresce já há um bom tempo no mercado editorial? Qual é a demanda que essas "tecnologias de si" vêm atender? Como interpretar a presença constante dos profissionais psi (psiquiatras, psicólogos, psicanalistas)

$\cot$

1 Universidade Estadual Paulista Júlio de Mesquita, Faculdade de Ciências e Letras. Av. D. Antônio, 2100, Parque Universitário, 19806-900, Assis, SP, Brasil. E-mail: <sjbewelli@yahoo.com.br>. 
na mídia ditando a pauta da "conduta adequada" para todas as circunstâncias da vida das crianças, dos adolescentes, dos jovens, dos adultos e dos idosos? Como se aceita com naturalidade - inclusive solicitando-se com avidez - essa psicologização prescritiva da existência humana? A que se pode remeter a ausência de uma perspectiva ético-política crítica em profissionais da psicologia quando realizam seu trabalho visando à prevenção ou à promoção de saúde? Como entender a pujança de fenômenos tais como a filosofia clínica, o eneagrama e a programação neurolinguística, bons representantes de novas modalidades e sistemas terapêuticos na atualidade? Neste trabalho acredita-se ser possível encontrar uma possibilidade para a compreensão de tais fenômenos na hipótese da expansão da cultura psicológica proposta por Castel (1987).

O objetivo deste estudo foi problematizar a excessiva psicologização da vida contemporânea, tomando como exemplos característicos desse fenômeno a filosofia clínica, o eneagrama e a programação neurolinguística. Para tanto, estudou-se a hipótese da cultura psicológica proposta por Castel (1987), procurando compreender as atuais transformações no campo social e sua incidência nas áreas da saúde mental (psiquiatria, psicologia e psicanálise), bem como alguns de seus possíveis desdobramentos nas práticas psicológicas atuais.

A metodologia utilizada nesse trabalho de revisão é uma modalidade de análise que se baseia no caso singular, estudado a partir de uma perspectiva dialética (Benelli, 2007; Benelli \& Costa-Rosa, 2006; Bock, Gonçalves \& Furtado, 2002). É possível justificar uma reflexão e análise dos processos de funcionamento e dos efeitos de um conjunto de tecnologias e sistemas terapêuticos com características semelhantes a partir de casos exemplares, caso se conceba a hipótese de que não se tratam de casos isolados e idiossincráticos, mas, pelo contrário, de casos singulares. Um caso pode ser considerado singular na medida em que encerra as informações essenciais sobre as características básicas do fenômeno que se procura compreender, e sobre os processos que aí se encontram em ação. O estudo da singularidade permite captar as determinações concretas constitutivas de um fenômeno social, pois o conhecimento produzido a partir de determinados 516 exemplares pode se constituir em uma instância defla- gradora da apreensão e do estudo de mediações que concentram a possibilidade de explicar a realidade concreta.

Há um mercado de bens de saúde mental em franca expansão, com ofertas muito variadas quanto a possibilidades de prevenção e de tratamento - entre elas, a gestalt-terapia, modalidades de aconselhamento psicológico, análise transacional, estratégias de intervenção psicológica e terapêutica em instituições e comunidades, filosofia clínica, eneagrama e programação neurolinguística - que promovem a criação de uma sociabilidade relacional e o surgimento de terapias para pessoas normais que visam ao desenvolvimento e aprimoramento individuais. A leitura de Castel (1987) funcionou como um operador de análise que permitiu articular uma reflexão em torno do conceito de "cultura psicológica" como hipótese explicativa para essa psicologização da existência humana que predomina na atualidade.

Com relação à literatura pertinente, realizaram-se diversas pesquisas em bases de dados nacionais, tais como BVS-PSI, SciELO, Index Psi, Qualis A Nacional, utilizando as palavras-chave do artigo, mas o intuito de atualizar as referências não foi atingido com êxito: poucos foram os trabalhos relevantes e atuais com potencial de enriquecer a investigação aqui descrita. Isso indicou que a temática ainda não foi explorada e devidamente desenvolvida, o que se pretendeu fazer por meio desta pesquisa. A literatura citada, mesmo as obras menos recentes, continuam sendo referência obrigatória e inclusive clássica no caso de publicações relativas ao eneagrama, à filosofia clínica e à programação neurolinguística.

\section{A formação de uma cultura psicológica}

Castel (1987) realizou uma análise genealógica das transformações no campo psi francês abrangendo as décadas de 1970 a 1980, procurando compreender a atualização do setor psiquiátrico, o esgotamento da psicanálise, a medicalização da saúde mental, a nova política de gestão dos riscos sociais e, por fim, o surgimento de uma nova cultura psicológica, anúncio e advento de uma nova ordem pós-disciplinar. Sua leitura funcionou como um catalisador que permitiu organizar uma série de inquietações em relação a algumas 
tecnologias de si na atualidade. A categoria de cultura psicológica é um analisador que possibilita a compreensão de todo um conjunto de novidades terapêuticas e paraterapêuticas observáveis no campo psi brasileiro. Entende-se que Castel (1987) realizou uma análise historicamente singular de questões de alcance geral, ao menos no contexto das sociedades ocidentais.

Ferreira Neto (2004) realizou um estudo genealógico sobre a formação do psicólogo brasileiro, mapeando na história recente do Brasil o esgotamento da clínica médica, psicanalítica e psicológica de corte liberal, a emergência e a problematização de movimentos sociais pela psicologia, o surgimento de novas práticas de intervenção e pesquisa psicológica no contexto social e, finalmente, os perigos do mercado neoliberal globalizado para a psicologia. Sua pesquisa apresenta fortes ressonâncias com as análises de Castel (1987), evidenciando a pertinência do diagnóstico por ele realizado.

Castel (1987) considera que se vive no bojo de uma nova cultura psicológica, em um movimento de superação da antipsiquiatria e pós-psicanálise. Atualmente, as técnicas médico-psicológicas já estariam ultrapassando as balizas clássicas do recorte do normal e do patológico, da problemática da prevenção e do tratamento, em direção a um processo de programação de si permanente. O que se visa na cultura psicológica não seria a prevenção nem a cura das disfunções, mas o autodesenvolvimento psicológico interminável do indivíduo. O mundo e a vida passam a ser compreendidos e interpretados como algo psicologicamente administrável e transformável, em um processo de psicologização crescente da totalidade da existência humana. A perspectiva cultural atual localiza e circunscreve na psicologia a plenitude da vocação social dos indivíduos: o objetivo seria então tratar o indivíduo normal e a sociabilidade comum.

Na origem dessa cultura psicológica, Castel (1987) detectou a desestabilização da psicanálise e sua dissolução em uma cultura psicanalítica de massa. A psicanálise teria dado caução teórica e técnica para a psicologia clínica e para outras profissões centradas na relação interpessoal e na ajuda (assistentes sociais, educadores, professores, pedagogos, advogados). Na grande nebulosa do psicológico, "estabeleceu-se um consenso para fazer da criança em relação ao homem, e da criança em cada homem, a chave de seu destino pessoal e o princípio explicativo essencial de sua história" (Castel, 1987, p.135). Se o fascínio pela psicanálise intensificou um interesse generalizado pela psicologia, transformando o discurso psicanalítico no principal codificador psicológico da existência humana, também retirou da psicanálise sua especificidade, banalizando-a enquanto denominador comum de um meio cultural.

\section{O novo arquipélago psicológico}

Novas técnicas e práticas estão constituindo o novo arquipélago psicológico. Elas podem ser agrupadas sob o título de "movimento do potencial humano" ou "psicologia humanista". Castel (1987) as considera pós-psicanalíticas, pois elas partem da psicanálise, superam-na e conservam algo de seu discurso, mesmo que a neguem. São heterodoxas com relação à psicanálise, e"confluem para propagar uma cultura psicológica que se universaliza, perdendo a memória de suas origens e o cuidado de seus fundamentos teóricos" (Castel, 1987, p.141).

Tal arquipélago seria constituído pela bioenergia (Fadiman \& Frager, 2005), a gestalt-terapia (Fadiman \& Frager, 2005), pelas diversas modalidades de aconselhamento inspiradas em Carl Rogers (Fadiman \& Frager, 2005) e pela análise transacional (Berne, 1974; Harris, 1974; Meininger, 1985). Pode-se acrescentar a essa lista de Castel (1987) uma vasta literatura de autoajuda mais contemporânea, bem como diversas estratégias de intervenção psicológica terapêutica e preventiva junto a instituições e comunidades consideradas em situação de risco social, além da filosofia clínica, do eneagrama e da programação neurolinguística.

A literatura de autoajuda, em suas numerosas variedades, com inovações técnicas mínimas, inventa novos apelos para se colocar no mercado de bens psicológicos à disposição dos consumidores. Caracteriza-se por uma crítica superficial da autoridade, das obrigações e hierarquias; cultiva a espontaneidade, prega a busca insistente da autenticidade pessoal, valoriza a não diretividade e uma convivência grupal informal. O corpo é o suporte e o alvo de sua ação e sua principal estratégia baseia-se em atividades grupais (Silva, 2005). A atividade terapêutica consiste em exercícios de expressão corporal que visam à liberação de cargas energéticas e 
emocionais reprimidas ou bloqueadas no corpo (Castel, 1987).

Qual é o objetivo desta plêiade de terapias para pessoas normais? Seria justamente desenvolver o potencial humano inato do indivíduo, buscando a integração da totalidade da pessoa com suas emoções e inteligência, seu corpo e seu espírito, seu pensamento e sua capacidade de ação. Representam a possibilidade de trabalhar o conceito de normalidade, já que o desenvolvimento e o equilíbrio psíquico são teoricamente intermináveis. A normalidade não é um estado definido, mas uma situação na qual sempre se pode intervir, buscando seu desenvolvimento e aprimoramento. "O recurso a uma tecnologia psicológica não tem por único objetivo reparar (curar), nem mesmo manter a saúde (prevenir), mas pode servir para explorar, aprofundar, trazer um acréscimo que não se contentaria em calafetar um disfuncionamento" (Castel, 1987, p.144).

Como a psicanálise ensina que o trabalho sobre si é virtualmente universal, ela acaba criando uma demanda social à qual não pode responder. As novas terapias superam o elitismo que a psicanálise supõe na sua implementação prática (recursos econômicos, culturais e tempo disponível para o tratamento). Elas oferecem um tipo de tratamento que pode ser realizado em fins de semana no campo, em sessões de grupo semanais, durante alguns meses. No decorrer do itinerário terapêutico, propiciam o estabelecimento de novas relações interpessoais, a vivência de aventuras, o surgimento de amizades, de eventuais relacionamentos amorosos e até a possibilidade de se tornar um novo animador e divulgador de uma técnica determinada, encontrando e criando, assim, uma forma de trabalho e de obter rendimentos.

Pode-se falar então de "terapias para os normais" (Castel, 1987, p.145): a normalidade torna-se sintoma. Há uma crítica superficial da vida social enquanto lugar no qual se vivenciam constrangimentos absurdos, exigências desmedidas quanto ao êxito e ao rendimento no trabalho, incompatíveis com a liberdade e a expansão pessoal; vivências nas quais não há naturalidade e espontaneidade nas relações entre as pessoas. Além disso, afirma-se que a pessoa pode ser objeto de um trabalho que the permite desenvolver seu potencial e intensificar sua capacidade de se relacionar bem com

518 os demais. Isso seria feito por meio da utilização siste- mática de técnicas psicológicas diversas:"O acabamento do ser humano torna-se uma tarefa infinita, na qual não se terá nunca acabado de investir" (Castel, 1987, p.145).

Esta nova estratégia de intervenção tem como tarefa tanto atender à doença que produz infelicidade quanto cultivar um desenvolvimento pessoal que promete a felicidade. As abordagens denominadas "humanistas" generalizam a possibilidade de invadir e colonizar rincões da existência privada, da intimidade e da intersubjetividade, que estavam isentos de antigos empreendimentos de racionalização e segmentação; estes, por sua vez, visavam à mensuração e manipulação do indivíduo enquanto estudante, trabalhador ou doente. As abordagens humanistas focalizam o homem em sua totalidade, procurando instrumentalizá-lo globalmente. Conjugam uma crítica social ligeira com uma concepção pragmática da pessoa. Buscam a receita para tornar o homem livre por meio de técnicas, construir sua espontaneidade com atividades programadas e combater sua alienação com uma bateria de exercícios corporais.

As novas abordagens terapêuticas estão batendo na porta das instituições públicas de saúde e podem ser integradas em diversos programas de tratamento, apresentando algumas vantagens: podem ser aplicadas em grupos, alguns de seus resultados são rapidamente percebidos e avaliados, e também conservam algo do significado usual das psicoterapias (Casella, 2004; Silva, 2002). Mas, superando as técnicas de intervenção no campo da patologia, elas avançam e atraem um novo público, propondo uma concepção ampliada da relação terapêutica:

... essas abordagens, aliviando o apetite da psicologia por novas franjas da população, estendem-se à esfera do que se poderia chamar o "paraterapêutico", quer dizer, esta nebulosa de intervenções que engorda nos limites da patologia e do mal-estar existencial. O sentimento de viver ao lado de sua vida não suscita realmente uma demanda de terapia: não é uma doença, mas sobretudo um conjunto de insatisfações e de frustrações, que recortam ao menos em parte algumas motivações da clientela da psicanálise, mas podem ser, a partir de então, tratados de um modo ao mesmo tempo menos caro, mais democrático, mais flexível e mais selvagem (Castel, 1987, p.149).

Um vasto mercado de bens de saúde mental constitui-se entre os setores clássicos e privados próprios 
da neuropsiquiatria e da psicanálise por um lado, e as instituições públicas de saúde mental, que inclui hospitais psiquiátricos e ambulatórios diversos, por outro. Surgem novas demandas e respostas inéditas a elas: as diversas abordagens terapêuticas, paraterapêuticas, inclusive extraterapêuticas, focadas na atenção relacional e também na cura, que estão colonizando setores que sempre foram estranhos para a clínica clássica, tais como a empresa, o comércio e a publicidade. Uma operação eclética está injetando essas tecnologias relacionais em novos setores, pois, como abarcam as fronteiras do normal e do patológico, seria natural encontrá-las onde exista algum tipo de problema relacional. Um discurso que propõe a "formação permanente e contínua", a "reciclagem" e a atualização permanente no campo do trabalho profissional fomenta sua expansão:

O imperativo que põe para frente essa ideologia do renovamento perpétuo é aprender você mesmo a mudar, quer dizer, a exigência de trabalhar na sua própria disponibilidade e sua flexibilidade relacional, pelo menos tanto quanto seus conhecimentos. Como de fato enfrentar as mudanças tecnológicas e os imperativos da concorrência, se não fazendo do trabalhador um ser sem asperezas e crispação, cujas capacidades são mobilizáveis a qualquer instante? Mas como conseguir isso, se não for perseguindo seus bloqueios e suas resistências, cultivando uma espontaneidade reencontrada, capaz de responder às injunções do presente? (Castel, 1987, p.150).

As novas tecnologias do relacionamento invadem o mundo do trabalho e inclusive alcançam os desempregados, pois, sobretudo para eles, é preciso reciclar-se, melhorar ou inovar suas competências com relação a futuros trabalhos. Os desempregados constituem uma numerosa matéria-prima de uma nova indústria de aprimoramento do capital humano: eles estão em condições ideais para aprender a mudar, pois formam uma força de trabalho completamente disponível, com condições perfeitas de reciclagem. Assim se desenvolve um mercado de promoção do relacional. Essas novas modalidades terapêuticas da normalidade inscrevem-se sem solução de continuidade, no movimento psicologizante mais amplo que, desde o século XIX, desenvolve recursos de uma competência psicológica para o equacionamento de problemas pessoais clínicos, existenciais e organizacionais (empresariais, escolares). Qual seria sua novidade?
A novidade, de fato, é dupla. De um lado, um tal programa pode ultrapassar as piedosas declarações de intenção para se instrumentalizar numa ampla escala, porque dispõe de uma panóplia nova de técnicas. Em segundo e, sobretudo, tomando-se a si mesmo como objeto e fim de uma experimentação psicológica, o homem descobre uma propriedade inesperada do trabalho psicológico, a de criar ela mesma uma forma nova de sociabilidade. A "cultura das relações" empreendida de longa data por meio da psicologia está desembocando numa "cultura relacional" no seio da qual a mobilização psicológica se coloca como um fim em si, que satura todos os valores da existência (Castel, 1987, p.151).

\section{A criação de uma cultura relacional}

Um exemplo da construção dessa vida em rede pode ser observado em uma subcultura relacional. Os "grupos de encontro" (Fadiman \& Frager, 2005, p. 241-245) são uma estratégia típica para a experimentação e aprendizagem de várias dessas modalidades tecnológicas relacionais. Um grupo pode se encontrar durante vários fins de semana, em uma sessão semanal noturna, durante algumas semanas ou meses sob a condução de um "animador" ou "assessor". Os participantes, que geralmente não se conhecem, vão livremente e pessoalmente motivados. A atmosfera das reuniões costuma ser informal, colocando entre parênteses as formas comuns de sociabilidade. Há duas regras fundamentais: a aceleração dos contatos e a maximização das emoções, mas a interlocução acontece entre pessoas que são em si mesmas "totalidades realizadas de uma existência na eternidade de um presente sem referências sociais e sem gênese histórica" (Castel, 1987, p.152). A livre expressão emocional leva"a uma encenação da vida social sob a forma de sua histerização, numa grandiloquência, uma desmesuração" (Castel, 1987, p.152) que permite passar imediatamente do paroxismo emocional ao comportamento normal.

Assim, cria-se uma sociabilidade que se basta a si mesma, completa em seu acabamento. Há uma crítica da sociedade enquanto produtora de alienação, repressão e exploração das pessoas, reificadora dos relacionamentos interpessoais, mas não há uma análise desses mecanismos sociais em si mesmos, da efetividade das estruturas de saber e poder que se encarnam nas 
instituições e nas classes sociais. A alienação social é reduzida e interpretada no plano da individualidade, tendo apenas implicações pessoais. Deste modo, a liberação só pode ocorrer por meio de estratégias individuais:

Oposição não dialética à sociedade, já que ela se contenta em inverter os sinais da alienação: à negatividade dos constrangimentos se opõe a positividade de uma natureza. Mas, na medida em que a alienação pré-existe, a natureza não vem por acréscimo e é preciso reconstruí-la por técnicas psicológicas, trabaIhar no espaço do grupo a imanência da pessoa para dela fazer jorrar o modelo de uma sociabilidade vivível (Castel, 1987, p.153).

O trabalho sobre o eu tem um caráter descontínuo e os indivíduos buscam sempre novas experiências grupais, pois a efervescência grupal torna-se um estilo de vida e um modo de existência. Procuram uma aprendizagem experiencial por imersão e buscam com voracidade o ápice da intensidade emocional. Desenvolvem uma linguagem própria e uma forma típica de entrar em contato que se caracteriza ao mesmo tempo pela intensidade e por uma ausência de implicação, como se tudo se resumisse ao presente, ao aqui e agora. "Intensificação das relações, mas sem o quadro de um comércio inscrito nas estruturas sociais e na história, a cultura psicológica vê-se como um fim em si" (Castel, 1987, p.154).

As novas técnicas dessa cultura psicológica promovem um modo de existência cujo objetivo é o desenvolvimento do próprio potencial psicológico e a intensificação de suas relações com os demais.

Em uma situação na qual a conjuntura histórica revela um esgarçamento dos investimentos sociais, uma degradação em larga escala das estruturas da sociabilidade normal - baseada em afinidades culturais e eletivas, em diferenças estatutárias e em obrigações sociais codificadas - na qual a família e o trabalho, fatores essenciais de integração social, se esfacelam, qual seria o significado das novas tecnologias de si? Observa-se ص uma não integração social dos indivíduos e a ausência 罚 de laços sociais, um temor diante do fim do emprego m ou ainda um desinteresse pelo próprio trabalho, além de crise nas perspectivas políticas. A vida já não é vista como pontuada pela sucessão de certo número de papéis sociais significativos, que vão da aprendizagem à aposentadoria. Há uma perda da credibilidade nessa trajetória e as determinações sociais deixam de ter uma função definidora para o indivíduo. Neste caso, a pessoa "torna-se o itinerário obrigatório de um percurso infinito cujo desenvolvimento de seu próprio potencial é a única lei" (Castel, 1987, p.156). Quando as estruturas de plausibilidade do social e do político se exaurem, o vácuo pode ser ocupado pela cultura psicológica, na qual "a psicologia torna-se o objetivo primário, constituindo uma sociabilidade vazia de qualquer outro conteúdo, a-social-sociabilidade..., que se esgota a desdobrar uma combinatória relacional comportando seu fim em si mesma" (Castel, 1987, p.156).

\section{Uma nova sociabilidade psicologizada}

Há uma crítica tradicional da psicologia que tende a denunciar seu papel de mascaramento ideológico das condições materiais e históricas de produção da vida social, psicologizando e promovendo uma interiorização dos conflitos sociais, localizando-os em uma hipotética interioridade psíquica dos indivíduos. Criando um plano psicológico interno ao indivíduo, a psicologia elaborou teorias e técnicas de intervenção para lidar com os problemas afetivos e relacionais das pessoas, denegando as relações sociais capitalistas concretas que impõem determinações para a vida coletiva e individual. Porém Castel (1987) afirma que há um elemento novo na conjuntura contemporânea, pois a psicologia não apenas funciona como uma recodificação ideológica, mas está se constituindo como análoga do social:

... o psicológico está se tornando o social de um mundo sem social. Da mesma forma que, no campo religioso, investe-se todo o poder que o homem não pode desdobrar no mundo real, o psicológico invade e satura novos espaços liberados pelo refluxo do social, faz a vez de social representando o estatuto de uma sociabilidade completa quando os fatores propriamente sociais escapam ao domínio dos atores (Castel, 1987, p.157).

Esta inflação da psicologia deve-se às atuais transformações da estrutura social: a ordem pública, caracterizada por jogos de rituais sociais que organizam a existência social, está sendo substituída por produções exclusivamente do plano subjetivo. A desintegração das estruturas clássicas de coesão social leva os indivíduos 
a construírem novas formas de sociabilidade. Os novos laboratórios de experimentação social poderiam ser verificados nos diversos tipos de reuniões ou de encontros grupais que são implementados pelas novas tecnologias relacionais, promotoras de pequenas unidades relacionais participativas.

A família estaria em crise e perdendo algumas de suas funções tradicionais de reprodução social e econômica: a transmissão do patrimônio (que foi substituída pela primazia da renda individual), a gestão das alianças (os filhos atualmente possuem círculos sociais autônomos), a promoção social de seus membros (as possibilidades de ascensão social estão cada vez mais restritas). Apenas as famílias tradicionalmente poderosas permanecem organizadas em torno do gerenciamento de seu capital econômico, cultural, social e demográfico. Às famílias de nível médio e baixo restou apenas a administração do seu "capital relacional": as relações e os laços emocionais, os relacionamentos entre seus membros, o casal e seus filhos. Este núcleo sentimental tornou-se o ponto de resistência da estrutura familiar quando da espoliação de suas funções sociais; ela sobrevive agora fundamentalmente como estrutura relacional. Há uma produção de mercadorias psicológicas centradas na sexualidade e na infância, instrumentalizando a sexualidade conjugal e procurando intensificar sua relação afetiva, além de buscar programar uma harmonia educativa improvável em relação às crianças. A família normal seria hoje a maior consumidora de psicologia, buscando nesse artigo luxuoso de perfumaria uma mais-valia de harmonia e de beleza (Castel, 1987; Silva, 2005).

No campo do trabalho, a globalização da economia define os aspectos essenciais do modo de funcionamento das empresas e imperam as leis do mercado, que marcam os limites do negociável:

Que resta então a decidir num organismo de produção, quando o essencial é decido em outro lugar? Reagenciamentos internos, rearrumações na distribuição das tarefas, melhoras na maneira de as informações circularem na transmissão das ordens, na percepção dos subordinados para o que se lhes pede - e que, de qualquer maneira, eles serão obrigados a fazer (Castel, 1987, p.156).

Para a psicologia fica então a tarefa de promover a regularização das relações no contexto da orga- nização, gerenciando um conjunto de problemas que podem ser tratados e elaborados no quadro da empresa enquanto uma unidade funcional. Nas empresas, "a promoção do relacional se desenvolve no vácuo deixado pelo deslocamento de um certo número de centros reais de decisão ..."(Castel, 1987, p.161). O que essa psicologização das relações de trabalho está produzindo? Ela pode intensificar as capacidades de trabalho dos funcionários e aumentar os lucros da empresa, pode ainda desmontar conflitos sociais. Mas pode, sobretudo, maximizar a exploração, mobilizando todas as energias das pessoas em benefício da empresa, por exemplo, através de"novas técnicas de gerenciamento que consistem em delegar amplas margens de iniciativa e a transformar, na medida do possível, os executantes em decididores" (Castel, 1987, p.161). Haveria aí uma apropriação do modelo da autogestão - um dispositivo altamente revolucionário - e sua aplicação tecnológica assepsiada pelo capital, ou seja, limpa e isenta de todo seu potencial político altamente corrosivo e transformador.

A intenção é superar a mera adaptação do indivíduo ao contexto de trabalho, promovendo uma intensificação de suas potencialidades e visando a uma maior extração de mais-valia. Em um sistema de produção no qual as imposições objetivas da economia encontram-se fora do alcance dos indivíduos, o que é possível trabalhar são suas relações e seu potencial pessoal. Seria isso que as novas tecnologias psicológicas estariam propondo como programa permanente.

As regras do jogo social começam a ser modificadas em função dessa sofisticação estratégica do capital que se apropria e instrumentaliza a psicologia. Pode-se falar de uma sobrecodificação da subjetividade pelas centrais hegemônicas de produção e de distribuição de sentidos no campo social. O capital descobriu a importância do grupo e dos ideários da participação e autogestão para a extração de mais-valia. Há tempos ouvem-se novas palavras de ordem no discurso empresarial:"flexibilidade","desenvolvimento de competências", "capacidade de adaptação", "desenvolvimento da criatividade", "busca de resultados", "agregar valores", "interdisciplinaridade", "desenvolvimento estratégico", "qualidade total", "capacidade empreendedora". Esse discurso impulsiona a mudança no mundo do trabalho, porém se trata mais de mudar o trabalhador individual do que 
propriamente transformar as relações de trabalho. 0 trabalhador ou o candidato a um emprego passa a representar um "conjunto de disposições pessoais que é convidado ele mesmo a cultivar" (Castel, 1987, p.162).

A psicologização do mundo do trabalho, centrada no gerenciamento das relações interpessoais ou no desenvolvimento de uma cultura relacional, tem elaborado teorias que pretendem ser inovadoras, importando conceitos do campo do esporte, da guerra e da física. Por exemplo, teorias do gerenciamento empresarial criam moda lançando mão de termos tais como "sinergia" e "resiliência" (Barlach, 2005; Pinheiro, 2004), aplicando-os à gestão de pessoas e de negócios. O termo que representa a última novidade do momento aplicado no mundo empresarial é "resiliência". Trata-se de um conceito pinçado da física que denomina a propriedade de alguns materiais de acumular energia, quando exigidos e estressados, e voltar ao seu estado original sem qualquer deformação. Uma das competências e habilidades individuais exigidas pelo mercado na atualidade é a flexibilidade, a habilidade do elástico ou da vara do salto em altura, que se enverga no limite máximo sem se quebrar, volta com força ao seu estado normal e lança o atleta para cima, por sobre o sarrafo. Os conceitos de sinergia e resiliência prestam-se para os projetos tecnocráticos de "reengenharia" e de "qualidade total", que se pautam pelas noções de enxugamento de pessoal, recrudescimento da competitividade e da pressão, visando a uma maior exploração da força de trabalho de um número reduzido de funcionários. A ideia básica é cortar despesas, aumentar a produção e a lucratividade. Os funcionários devem, então, se tornar máquinas eficientes, programadas para produzir em sinergia, competir e ser resilientes (Tavares, 2001; Yunes, 2003).

Metáforas brilhantes e encantadoras podem ser utilizadas pelo capital para a promoção da programação de si em busca da eficiência, rendendo lucros cada vez maiores, persuadindo discretamente os trabalhadores a aderirem a esse discurso que prega sua modulação permanente, mas não questiona as condições que o mercado impõe. A programação de si funciona menos por meio de coerção e mais por uma prescrição de comportamentos. A função política desempenhada pela

522 psicologia no contexto da produção está superando a mera dissimulação ideológica e rumando para a criação de novas realidades sociais. Nas transformações atuais das dimensões públicas e privadas, a psicologia vem sendo dotada de uma realidade autonomizada, pois as opções econômicas, sociais e políticas ficam fora do alcance do indivíduo. Sua subjetividade "livre" só produz objetos derrisórios. "A constituição de uma sociabilidade saturada pelo psicológico cria o último teatro onde se desdobra uma cultura relacional que não pode ter outra finalidade além de sua própria reprodução" (Castel, 1987, p.163).

Na cultura psicológica há uma superdeterminação da subjetividade e da intimidade que remete à cultura do narcisismo proposta por Lasch (1983), mas ela também contempla um projeto de sociabilidade, embora fracassado, que é indicado pela primazia da instância grupal (Silva, 2005) nas novas e variadas tecnologias relacionais. "Não investimento do social e do político de um lado, superinvestimento do psicológico do outro: o lugar da cultura psicológica é no vácuo deixado por essa dialética" (Castel, 1987, p.166).

De acordo com Castel (1987), a emergência da cultura psicológica pode ser mapeada na confluência de vários fatores: a) há uma ampla divulgação de esquemas de interpretação e de técnicas psicológicas cujas origens podem ser mapeadas nas formulações da clínica clássica (medicina, psiquiatria, psicanálise), mas superando as fronteiras do patológico e abarcando a normalidade (aprimorando tecnologias psicológicas da psicopedagogia, da psicologia organizacional e do trabalho, psicologia grupal e comportamental), com caráter terapêutico, paraterapêutico e extraterapêutico, objetivando uma programação permanente do homem; b) as transformações profundas das estruturas sociais promovem uma retomada dessas tecnologias psicológicas em experiências grupais e corporais de trabalho sobre a sociabilidade normal (as intervenções racionalistas da psicologia foram substituídas por técnicas de intervenção sobre o corpo); c) a consolidação de centrais anônimas e hegemônicas de poder econômico, político e simbólico, como detentoras das decisões quanto aos rumos das relações entre a ordem pública e a vida privada - que escapam ao domínio dos atores históricos -, induz nos indivíduos uma intensificação das práticas relacionais, único espaço de manobra que lhes 
resta. Haveria um desprendimento completo e progressivo da cultura relacional quanto às suas origens clínicas e aos grupos que as instrumentalizaram, passando a constituir novas formas de sociabilidade:"a análise da cultura psicológica desemboca assim nessa terra de ninguém, onde as fronteiras entre o psicológico e o social se embaralham porque uma sociabilidade programada por técnicas psicológicas e relacionais representa o papel de substituto de um social em crise" (Castel, 1987, p.168).

\section{A gestão dos riscos como forma de administrar populações problemáticas}

Ultrapassando os limites classificatórios do normal e do patológico, haveria um movimento na direção de novas tecnologias encarregadas da tarefa de gerenciar faixas da população que representam problemas para os administradores da ordem social vigente. Há não apenas um reforçamento do dispositivo tradicional de intervenção psicológica baseado no tratamento clínico e na prevenção, mas também a emergência de estratégias inéditas que atingem um número muito maior de indivíduos:

A gestão diferencial das populações não se situa na continuidade de sua segregação no seio dos espaços fechados, e difere igualmente do intervencionismo assistencialista dos programas de psiquiatria comunitária. Há igualmente deslocamento dos objetivos perseguidos, já que técnicas de intensificação do funcionamento normal se superpõem, a partir de então, às das que propunham reparar disfunções (modelo clínico) ou evitar que ocorram (modelo preventivo). Orientações igualmente dinâmicas parecem corresponder a intencionalidades divergentes: simultaneidade de uma volta ao objetivismo médico e de uma fuga para a frente na cultura psicológica, por exemplo, ou reforço dos controles centralizados, apoiados pela informática e encorajamentos dados aos movimentos associacionistas para maximizar as responsabilidades da iniciativa particular (Castel, 1987, p.170).

A unidade entre as práticas tradicionalmente encarregadas da cura e da prevenção com as novas tecnologias da intensificação da normalidade residiria na sua complementaridade na consecução de um objetivo comum: elas se inscrevem em uma estratégia geral de gestão das diferenças, das fragilidades e dos riscos que caracterizam as atuais sociedades neoliberais, pautadas por um modelo naturalizado e reducionista de humanidade, tomada como espécie ou série, como um sistema e uma totalidade administrável. Nesse sentido, em um polo formado pela medicina, pela pesquisa científica e pela administração pública, predominaria o objetivismo científico, visando ao gerenciamento dos disfuncionamentos e riscos mais objetivos - buscando, por exemplo, no código genético e em fenômenos bioquímicos a causa das perturbações psíquicas - ou ainda aplicando a tecnologia da informática na ação sanitária no campo social, lidando apenas com fluxos abstratos de populações. Por outro lado, em um polo mais pragmático, a nova cultura psicológica estaria se encarregando de fragilidades subjetivas (mal-estar e insatisfações diversas), escapando desse reducionismo e caracterizando-se por um humanismo centrado na pessoa, no presente, na procura da autenticidade pessoal, na busca de relações transparentes com os demais: "Mas essa meta se realiza diminuindo a trajetória da pessoa no hic et nunc [aqui e agora] da experiência imediata e intensificando a relação a outrem a uma capacidade técnica de comunicar" (Castel, 1987, p.172).

Essa "psicologia humanista" está focada no desenvolvimento do potencial humano em suas dimensões pessoais e relacionais, e procura cultivá-lo visando a uma sociabilidade, um trabalho e um prazer mais satisfatórios. "Lutar contra as alienações torna-se assim uma tarefa programável cujas etapas são mensuráveis, ao longo dessa espécie de percurso do combatente, que é o empreendimento da liberação pessoal" (Castel, 1987, p.172). O modelo de homem que se pretende operacionalizar integra as dimensões da contemplação e da ação, experiências de êxtase e de catarse, com influências de um orientalismo cosmológico que propõe a circulação energética corporal (Fadiman \& Frager, 2005). A pessoa é reinterpretada no contexto de um pragmatismo total:

Esse pragmatismo domina hoje o campo das chamadas paraterapias, atingidas pelas insatisfações afetivas ou sexuais, as dificuldades conjugais ou familiares, os problemas da solidão e do mal-estar existencial - o que alguns chamaram "doenças da civilização"e sobre as quais não se sabe muita coisa, salvo que não têm a 
ver com a medicina nem com as tecnologias de intervenção mais "científicas". As novas abordagens correspondem assim a demandas específicas levadas por um público diferente daquele que freqüenta as instituições mais tradicionais e os profissionais mais clássicos. Elas ampliam o círculo daqueles cujos problemas talvez provenham de uma intervenção especializada suavizando a maneira como isso é proposto e dispensado (Castel, 1987, p.173).

\section{O mercado globalizado e o indivíduo programado: a ordem pós-disciplinar}

Quais as relações que esse panorama objetivista e científico, personalista e pragmático mantém com o contexto sociopolítico contemporâneo? No plano das políticas de saúde, haveria um recrudescimento de novas formas de controle centralizado, graças aos sistemas informatizados, conjugado com um movimento de descentralização e de municipalização, desenvolvendo nichos de liberdade vigiada, pois os setores locais são chamados a gerenciar por si mesmos as obrigações que Ihes são impostas. A organização estrita articula-se com experiências "participativas" circunscritas.

Haveria ainda a conjugação de um setor econômico globalizado altamente competitivo, um mercado anônimo e determinante das regras políticas para as empresas, bancos e estados, um setor estatal que dispensa serviços coletivos e comunitários sofríveis e paliativos e, finalmente, o setor da sociedade civil. Logicamente, a liberdade e o poder decisório do setor civil ficam praticamente comprometidos.

Um pequeno número de executivos toma as decisões políticas nas empresas, sob as diretrizes do mercado internacional. A política empresarial incita os trabalhadores à criatividade, ao desenvolvimento do seu potencial psicológico e relacional, buscando mobilizar sua espontaneidade para ser atuante no cenário imposto. As empresas são as maiores consumidoras dessas novas tecnologias da cultura psicológica. As instituições sociais em geral, e as de saúde em particular, também são atraídas pelo discurso e exigências da competitividade dinâmica.

Uma nova estratégia de poder se desenvolve, superando o poder repressivo: "a incitação a colaborar, de seu lugar e segundo suas necessidades, com a gestão das imposições no quadro de uma divisão do trabalho entre as instâncias de dominação e as que a ela se sujeitam" (Castel, 1987, p.177). A estratégia consiste em mobilizar voluntariamente os indivíduos submetidos às imposições para que eles mesmos assumam a responsabilidade de regulá-las, reunindo seu potencial pessoal e colocando-o a serviço da tarefa a desempenhar.

O sucesso dessa estratégia depende de uma modificação e redefinição profunda da pessoa, superando antigas tecnologias psicológicas:

\footnotetext{
A pessoa deve viver a exigência do hic et nunc [aqui e agora], saber se fazer acolhedora à eventualidade e ao acontecimento, estar apta a reagir a isso imediatamente. É o perfil psicológico promovido pelos técnicos do "trabalho sobre a normalidade", através de sua maneira de instrumentalizar a mudança pessoal. A analogia é pelo menos perturbadora entre esse novo homo psychologicus [homem psicológico] e a mobilidade requisitada por um ser sem história e sem raízes, capaz desse feito de reconverter ou de se reciclar a cada instante para responder às exigências de não importa qual planificação tecnocrática (Castel, 1987, p.177).
}

Se a crítica quanto às formas de intervenção médico-psicológicas estava focada na denúncia do caráter repressivo do modelo segregativo e assistencial utilizado para gerenciar o dissenso social, hoje há uma nova modalidade estratégica: não se busca mais apenas reparar ou prevenir disfunções, mas programar a eficiência. "Tal seria a ordem pós-disciplinar que não passaria mais pela imposição dos constrangimentos, mas pela mudança e gerência do fator humano em função das figuras novas sob as quais se apresenta a necessidade social" (Castel, 1987, p. 179).

O capital e o mercado globalizado atuam no gerenciamento direto das populações e também investem maciçamente na produção, reprodução e modulação de subjetividades. Há formas produtivas e outras de sujeição, submissão, formatação e controle da subjetividade. A estratégia atual supera a antiga técnica do confinamento, investindo na comunicação instantânea, no controle contínuo e na modulação, promovendo a flexibilidade subjetiva e seu constante ajustamento às demandas mercantis. A lógica empresarial vai colonizando o espaço social de modo capilar e o marketing torna-se um operador fundamental de 
controle social. Há uma insistência no cuidado com o corpo, na busca de criatividade, inteligência emocional e habilidades, empenho na superação de limitações pessoais e uma supervalorização da flexibilidade. Todos esses procedimentos de produção de subjetividade visam à programação de si em busca da eficiência.

Depois de elaborar o panorama da atual cultura psicológica, apresentam-se à sua luz análises sobre alguns fenômenos inquietantes: um deles está relacionado a estratégias de trabalho psicológico na saúde pública, outros seriam a filosofia clínica, o eneagrama e a programação neurolinguística como novas modalidades e sistemas terapêuticos. Apresentam-se, em seguida, tais tecnologias psicológicas sem a pretensão de fazê-lo de modo exaustivo. Esses casos podem ser compreendidos a partir da categoria da cultura psicológica proposta por Castel (1987). Ela permite entender as condições de possibilidade da emergência, vigência e pertinência desses fenômenos, tornando possível compreender seu modo de funcionamento e quais efeitos podem produzir e reforçar.

\section{Impactos da cultura psicológica no exercício dos profissionais da psicologia}

Silva (2002) apresenta uma metodologia para trabalhos de promoção de saúde e cidadania centrada nos conceitos de participação, prevenção e dinâmicas grupais para a aprendizagem de novos papéis sociais, voltadas para jovens e instituições da comunidade tais como escolas e unidades da Fundação Estadual do Bem-Estar do Menor (FEBEM). O objetivo seria uma "educação em valores para a mudança social" (Silva, 2002, p.8). A oficina é a técnica escolhida para a realização dos trabalhos grupais, pois permite uma postura reflexiva e ativa dos participantes, enfatizando o aspecto ativo e lúdico dos encontros, visando à produção de sentidos. O processo dialógico grupal permitiria a vivência de sentidos e a emergência de novas percepções sobre os fatos e acontecimentos, além do exercício do respeito às diferenças. "Os grupos possibilitam aos jovens ressignificar a experiência social e exercitar o respeito a si próprio e ao outro, num movimento dialógico de pensar e agir que permite que assumam e exercitem o papel de cidadãos" (Silva, 2002, p. 9).
A FEBEM propõe ao profissional psicólogo o desenvolvimento de atividades específicas em suas unidades:

O psicólogo deve realizar diagnóstico psicológico do adolescente/família e promover intervenção técnica necessária através do atendimento individual/grupo. Participar de reunião multidisciplinar que vise coletar informações adicionais do adolescente, bem como para integração e aprimoramento do trabalho. Elaborar relatório técnico psicológico em conjunto com o relatório técnico social e pedagógico para encaminhar ao Poder Judiciário. Discutir os casos com os profissionais do sistema de justiça quando necessário, bem como participar das audiências (FEBEM, 2006, p.13).

Em seus projetos socioeducativos, a FEBEM propõe que os adolescentes internados sejam atendidos por profissionais das áreas de pedagogia, psicologia e serviço social por meio de um atendimento sistemático e personalizado, levando o jovem a refletir sobre a infração por ele cometida. Esses profissionais têm como função corrigir, educar, modificar o comportamento e a conduta do adolescente infrator.

Casella (2004, p.14), ao tratar das estratégias de trabalho em psicologia institucional na saúde mental, no âmbito da saúde pública, afirma que nesse campo o psicólogo tem que trabalhar "na realidade de uma demanda inviável, no cerco dos entraves burocráticos e econômicos, que tantos profissionais paralisam", situação opressiva que tende a transformar profissionais idealistas em "funcionários públicos", no sentido pejorativo do termo.

O psicólogo é considerado um especialista em relacionamentos interpessoais. Casella (2004) é pragmática quanto à forma como ele deve lidar com a instituição: deve tratá-la do mesmo modo que faz com a clientela, partindo de uma postura técnica profissional relativamente imparcial, adaptando-se à sua estrutura de funcionamento e procurando atender à sua demanda de trabalho a partir da construção de um espaço de atuação. Não se coloca nenhuma questão crítica com relação à instituição quanto à sua função social e seus objetivos; seu contexto sócio-histórico e eventuais aporias não são problematizados. Os paradoxos institucionais devem ser encarados e enfrentados apenas na perspectiva profissional tradicional, focada no 
trabalho sobre os relacionamentos e as emoções individuais.

Nesses exemplos não se questiona a implicação ética do psicólogo quanto à psicologização da realidade existencial das camadas mais empobrecidas da população: há um constante deslizamento do plano da produção da vida material, marcada por relações antagônicas de exploração e exclusão que vigem entre o capital e o trabalho - portanto, do plano sociopolítico - para o campo da interioridade psicológica dos indivíduos. Eles continuarão em sua pobreza, pois não está nas mãos do psicólogo modificar isso, mas pelo menos estarão mais calmos, integrados, e seus relacionamentos serão mais gratificantes e realizadores.

Deste modo, não é difícil perceber que os recursos psicológicos teriam como função dissimular as reais contradições da vida social, escamoteando interesses mais amplos. A psicologia pode dissolver conflitos de classe por meio de técnicas terapêuticas e pode, assim, evitar que se coloquem em xeque os sistemas institucionais estabelecidos: é mais barato tratar crianças problemáticas e emocionalmente desajustadas do que transformar as estruturas sociais geradoras de tais indivíduos. Assim, a psicopedagogia apresenta-se como uma construção de respostas psicológicas aos problemas decorrentes das exigências do sistema escolar, e a psicologia organizacional visa ao equacionamento psicológico que o fator humano impõe para as exigências de produção das empresas.

Nessa perspectiva, qual seria a área de trabalho do psicólogo na saúde mental pública? Ele se ocupa da dimensão psicológica dos indivíduos que buscam por atendimento. A nebulosa do campo psicológico inclui, entre outros elementos, os sentimentos, as emoções, o comportamento e a capacidade racional do usuário. Os usuários dos serviços públicos de saúde são membros das camadas mais pobres da população. Junto ao baixo nível econômico vem a restrição do plano sociocultural e também a prioridade da sobrevivência.

O que o psicólogo pode fazer diante da inviabilidade de um trabalho clínico tradicional de "consultório"? As indicações de Casella (2004) revelam um forte ecletismo pragmático: ele deve lançar mão de uma ampla gama de recursos, estratégias e técnicas de trabalho psicológico: precisa utilizar reuniões grupais para orien526 tação e motivação da clientela, fazer um "so- ciodiagnóstico" (avaliação geral do cliente: nível intelectual, classificação da estrutura da personalidade, situação pessoal e familiar atual, descrição pormenorizada da sintomatologia), mais do que um psicodiagnóstico tradicional. A triagem da demanda inicial Ihe permitirá implementar diversas modalidades terapêuticas: grupos de orientação para mães, gestantes, familiares de alcoólatras, toxicômanos, delinquentes e doentes mentais; grupos de espera (com aconselhamento) para o trabalho terapêutico; supervisão da formação de grupos de aprendizagem diversos na comunidade; grupos de orientação em dias e horários viáveis para a comunidade; palestras sobre temas específicos e cursos de férias para outros profissionais da comunidade. Em suas orientações, a autora propõe ainda a utilização de técnicas psicodramáticas em grupos terapêuticos infantis e o uso da análise transacional em grupos de orientação com mães. Assim, é possível transferir os conflitos para o plano simbólico e torná-los conscientes para os indivíduos afetados, promovendo sua elaboração e catarse, modificando os comportamentos.

Por exemplo, o que faz uma equipe de prevenção implantada num quarteirão de imigrantes? Mudar as condições de moradia, encontrar trabalho para os adolescentes, modificar os reflexos racistas da população exterior? Os trabalhadores sociais estão bem colocados para saber que essas possibilidades de uma intervenção diretamente social ou política, estão na maioria do tempo fora dos limites de seu mandato. Então tecem redes de relações, tornam possíveis ligações afetivas, estruturam empregos temporários em torno de atividades que têm por fim intensificar encontros, despertar interesses, saturar desejos no quadro de uma sociabilidade construída por sua própria estratégia. Seu trabalho liga-se menos à possibilidade de agir sobre causas objetivas do que a sua capacidade de produzir um espaço de sociabilidade diferente das condições nas quais vive sua clientela (Castel, 1987, p.167).

Quando as dimensões sociais, políticas e econômicas que são determinantes das condições existenciais pessoais escapam completamente a qualquer possibilidade de intervenção e transformação, resta ao profissional da psicologia o trabalho de gerenciar e administrar o plano das relações interpessoais, enfocando o relacionamento humano, procurando melhorá-lo ou 
desenvolvê-lo e buscando superar seus bloqueios e traumas. Se transformar a realidade sociopolítica é inviável, porque o social já não existe mais (Silva, 2005), resta a criação do psicológico como espaço pessoal (interioridade psicológica) e interpessoal (relacionamento grupal baseado em técnicas psicológicas).

A inserção de muitos profissionais nos serviços de saúde públicos não supera a mera dimensão assistencial e adaptativa, propondo um ecletismo teórico-técnico na implementação de sessões grupais, de aconselhamento e oficinas. Essa "flexibilização" da clínica clássica nos serviços públicos e comunitários de saúde mantém sua função de normalização e controle social, produzindo subjetividades submetidas. O mercado globalizado busca capturar as práticas psicológicas emergentes e intensificar sua dispersão, colocando-as a seu serviço enquanto tecnologias para transformar as pessoas, inclusive induzindo a formação dos profissionais do campo "psi" a um tecnicismo acrítico (Ferreira Neto, 2004).

Silva (2002) e Casella (2004) parecem exemplares quanto a um certo discurso teórico-técnico bastante presente na formação dos profissionais da psicologia: o tratamento e a prevenção focados em um cuidado exclusivo com o plano relacional e emocional dos indivíduos, escamoteando o plano sociopolítico. Nessa perspectiva, o objeto da psicologia supõe o psiquismo como dotado de uma essência não histórica e invariável, próprio de uma natureza humana dada desde sempre e portadora de um eu profundo. Então, a psicologia estaria funcionando como uma tática para desmontar conflitos sociais e, ainda, por acréscimo, produzindo uma nova sociabilidade relacional. Nesse mesmo sentido, também é possível interpretar a presença constante do psicólogo na mídia prescrevendo a pauta de conduta adequada no âmbito das relações interpessoais para as diversas faixas etárias.

\section{A filosofia clínica}

A filosofia clínica (Aiub, 2004, 2005; Packter, 2001; Paulo, 1999, 2001), criada no Brasil pelo filósofo gaúcho Lúcio Packter, parece um caso exemplar de uma nova modalidade terapêutica para normais. Seria possível entender sua emergência no contexto da expansão da cultura psicológica proposta por Castel (1987) na realidade social brasileira.
Trata-se da filosofia acadêmica direcionada à clínica, realizada por filósofos graduados em faculdades de filosofia. Profissionais de outras áreas também podem cursar a filosofia clínica como uma pós-graduação e utilizar seus ensinamentos, em caráter introdutório, em suas áreas de atuação. Atualmente essa modalidade terapêutica abrange professores, especialistas, mestres e doutores em diversas cidades brasileiras. Possui página na internet, com muitas e variadas informações sobre o que é a filosofia clínica, como se organiza o Instituto Packter, as etapas e processos de formação dos terapeutas, bem como material para leitura, tais como artigos e bibliografia. De acordo com Packter (2001) a filosofia clínica utiliza teorias e autores da própria filosofia, não emprega tipologia nem critérios médicos ou medicamentos e drogas; procura localizar existencialmente a pessoa mediante os exames das categorias; o tratamento clínico tende a se efetivar entre 6 e 10 meses, com atendimentos máximos de dois encontros semanais de 50 minutos.

Como se forma um filósofo clínico? Depois de obter a graduação em filosofia em um curso reconhecido pelo Ministério da Educação, o interessado em se tornar filósofo clínico deve realizar um curso de especialização em filosofia clínica, que inclui as seguintes atividades: um mínimo de 24 meses de aulas com um filósofo clínico formado e estudar 18 apostilas do curso, chamadas de "Cadernos", identificados por letras: do Caderno "A" até o Caderno "R". Os alunos estudam os cadernos em casa; as aulas são práticas. Depois o aluno passa por um pré-estágio com um filósofo clínico instrutor, a contar do segundo ou terceiro mês de aulas.

Nesse pré-estágio, o filósofo clínico realiza os exames categoriais com o aluno. Este passa a frequentar aulas de argila, escultura, pintura, línguas, palestras, grupos de pesquisas de "submodos", estudos de filmes e atividades de caráter facultativo. Após o nono mês de aula, o aluno pode iniciar seu estágio supervisionado e vai clinicar um colega de aula e ser clinicado por outro; não há necessidade de se fazer isso dentro da mesma turma de aula. Tanto o pré-estágio quanto o estágio são documentados por gravações e transcrições; ao término dos trabalhos, esse material retorna invariavelmente ao cliente. Se o instrutor considerar que o aluno está apto a clinicar, este é autorizado a atender um ou dois clientes, além do estágio que está sendo feito. Contudo, esses 
atendimentos são obrigatoriamente supervisionados pelo filósofo clínico responsável.

Ao término das aulas e dos estágios, levando em conta a convivência com o grupo e com o instrutor, o aluno recebe o certificado "A" (apto à clínica e à pesquisa) ou o certificado "B" (apto somente à pesquisa, não à clínica). Então, o filósofo clínico recém-formado se inscreve no Conselho Regional de Filosofia Clínica (CRFC) e recebe uma carteira. Daí pode ser considerado devidamente habilitado em sua especialidade clínica (Packter, 2001). Essa novidade terapêutica endereça-se a indivíduos tomados por confusão mental, com dificuldades para tomar decisões, que estão sofrendo, dominados por medos e angústias existenciais, que estão em conflito com outras pessoas ou que estejam com problemas de relacionamento no trabalho e na família. São pessoas com essas queixas, entre outras, que buscam ajuda nos consultórios de filosofia clínica. Os sofrimentos são de caráter existencial; não são da ordem da doença nem se prestam a tipologias ou enquadramentos nosológicos. Aiub (2005) afirma que o importante nesse trabalho é o respeito à singularidade do outro, em um processo não invasivo e não diretivo, superando um mero aconselhamento filosófico e constituindo uma verdadeira clínica com procedimentos estruturados, de modo a permitir a identificação de sintomas que indiquem a necessidade de uma intervenção interdisciplinar.

O instrumental terapêutico da filosofia clínica é composto por três eixos fundamentais: os exames categoriais (que permitem o conhecimento do contexto existencial global do indivíduo), a estrutura de pensamento (composta de 30 categorias e seus desdobramentos) e os submodos (compostos de 32 categorias e seus desdobramentos) (Aiub, 2005; Packter, 2001). Uma ferramenta importante é a interseção, relação que se estabelece entre o filósofo clínico e o "partilhante", como é denominado o cliente.

Além da queixa que o levou a procurar atendimento e ajuda, busca-se ouvir a história de vida do partilhante, que servirá para a obtenção de dados quanto aos exames categoriais, estrutura de pensamento e submodos, visando estabelecer e manter a interseção entre terapeuta e cliente. A história de vida é recuperada e organizada, enquanto se tenta compreender os modos

528 de ser, pensar e agir do indivíduo e sua queixa, orga- nizando a partir desses elementos um planejamento clínico, estabelecendo as possíveis formas de auxiliar o partilhante. O que se busca é o "bem-estar subjetivo"do cliente. Os procedimentos da filosofia clínica são flexíveis, adaptáveis às necessidades de cada partilhante:

Ajuda ao outro, em Filosofia Clínica, não é sinônimo de oferecer um universo pronto a esse outro, e que não the pertence, transformando-o num outro eu, mas respeitar o seu universo, dispor-se a conhecê-lo e oferecer-lhe ajuda dentro das possibilidades encontradas nesse universo. Ajudá-lo a acomodar, a transformar, a modificar, a aceitar, a transmutar, a conviver... ao que for a sua escolha, diante de suas necessidades e possibilidades (Aiub, 2005, p.120).

A filosofia clínica é divulgada e se expande por meio do trabalho de filósofos clínicos que se uniram, formaram centros em cidades brasileiras e estão procurando aplicá-la a crianças, pessoas em situação terminal, obesos ou adolescentes, oferecendo consultoria a empresas, levando a clínica filosófica para colégios e faculdades. A formação de um filósofo clínico parece ter estrutura similar à de outras modalidades psicoterapêuticas clássicas que se baseiam no tripé básico: formação teórica, experiência pessoal de terapia e estágio clínico supervisionado. Outros elementos de destaque da filosofia clínica são a não diretividade, o ecletismo das teorias filosóficas que estão na base de sua proposta teórico-técnica e a liberdade quanto ao enquadre do tratamento. Sua clientela é constituída por pessoas assoladas pelo mal-estar típico dos tempos atuais (Bauman, 1998; Berman, 1990).

\section{O eneagrama}

Os sistemas psicoterapêuticos seriam aquelas instituições e dispositivos sociais (grupos de autoajuda - por exemplo, grupos de alcoólatras anônimos e similares) cujos membros são incorporados a sistemas de crenças e padrões de conduta que tendem a se constituir como estilos de vida. Os indivíduos incorporam-se a uma ideologia à qual "se convertem", modificando sua visão de mundo e condutas, com um impacto na sua vida emocional. Essa influência em sua vida emocional deriva de sua adaptação às normas do grupo. O grau de complexidade de tais grupos pode ser muito variado, incluindo grupos de escoteiros, alcoólatras anônimos, apoio a usuários de drogas, pessoas 
deprimidas ou excessivamente passionais e ciumentas com seus parceiros. Eles podem ser considerados psicoterapêuticos porque geralmente pretendem promover certo grau de desenvolvimento pessoal em seus integrantes, enfrentando maiores ou menores dificuldades conforme a complexidade do problema vivido por eles.

Talvez seja possível qualificar de sistema psicoterapêutico o eneagrama (Álvarez, 2001; Chabreuil, 1999; Cunha, 2005; Cunha \& Carlos, 1997; Naranjo, 1997; Múrcia, 2000; Palmer, 1993, 1999; Pangrazzi, 1997; Paterhan, 2003; Riso, 1994,1995; Rohr, 2000; Rohr \& Ebert, 1994; Salmon, 2000; Zuercher, 2001), um instrumento psicológico, ao mesmo tempo teórico e prático, que auxiliaria no conhecimento dos diferentes tipos de personalidade. É uma tipologia de personalidade que ajuda a identificar qual é o tipo da personalidade do indivíduo, oferecendo uma proposta de crescimento pessoal. Ele não se limita a revelar o tipo de personalidade, mas orienta sobre como crescer e melhorar o modo de vida do indivíduo.

A palavra "eneagrama" é de origem grega e composta de dois elementos: ennea, que significa nove, e gramma, que significa ponto. O termo eneagrama relaciona-se a um símbolo caracterizado por uma circunferência com nove pontos de referência relacionados entre si em uma determinada ordem, formando uma estrela. Esse símbolo tem origens muito antigas e servia para interpretar as leis do universo, compreender a cosmologia, a astronomia, a matemática, a filosofia, a química, a arte e a música. Parece que sua existência remonta a mais de dois mil anos atrás. É mais conhecido historicamente o papel desempenhado pelos mestres do sufismo medieval em sua utilização (Fadiman \& Frager, 2005). Os mestres sufistas teriam descoberto que, no processo de caminhar em direção a Deus, havia obstáculos recorrentes que impediam as pessoas de encontrarem a divindade. Essas barreiras, chamadas "paixões", coincidem com os sete pecados capitais da tradição cristã: ira, inveja, orgulho, avareza, gula, luxúria e preguiça, acrescidas de mais duas: o engano e o medo. Esses seriam os traços estruturais de caráter que constituem a espinha dorsal de nove tipos de personalidade. Os nove tipos são indicados por números de 1 a 9, e cada um deles também pode receber diferentes nomes. Nenhum dos tipos é melhor ou pior que os demais, pois cada um deles é caracterizado por qualidades e defeitos, obstáculos e desafios específicos.
Cada pessoa se enquadra em apenas um dos nove tipos básicos de personalidade. Esses nove tipos são padrões dinâmicos que podem ser classificados, cada um deles, em três estágios diferentes: tipo desintegrado, tipo normal e tipo integrado. O tipo desintegrado é caracterizado pelas piores condições desse padrão de personalidade: a pessoa encontra-se completamente dominada pelos defeitos e problemas do seu tipo básico. O tipo normal é caracterizado por aspectos razoáveis desse padrão de personalidade, mas que ainda são determinados pelo padrão rígido do tipo. $O$ tipo integrado é o melhor estado que o tipo pode chegar a atingir, desenvolvendo todas as suas potencialidades autênticas.

O eneagrama ensina que cada pessoa, pelos mais variados motivos, desenvolveu durante seu crescimento um padrão típico de personalidade. Esse padrão típico é inconsciente e funciona de modo automático, sem o conhecimento ou consentimento do indivíduo. É como se fosse um programa de computador que determina uma série de aspectos fundamentais da vida de todos: estados de ânimo, atitudes, pensamentos, sentimentos e comportamentos compulsivos e estereotipados. Os indivíduos atuam, sentem e pensam impulsionados por motivações inconscientes que condicionam seu comportamento global. Trata-se, então, de levar a pessoa ao conhecimento do seu padrão de personalidade, ajudando-a a compreender sua própria dinâmica de funcionamento. Com o eneagrama, revelam-se as imagens idealizadas de cada um dos nove tipos e como elas dificultam suas relações consigo mesmo, com os outros e com o ambiente. Cada tipo de personalidade é escravo de sua própria ilusão, que o indivíduo se sente obrigado a defender. Para libertar-se, deve descobrir suas motivações inconscientes e desmascarar seus jogos e enganos.

O eneagrama chegou ao mundo ocidental por meio de George Gurdjieff(1870-1949), de origem armênia, e Oscar Ichazo (1931- ), boliviano, atualmente residente nos Estados Unidos. Por caminhos diferentes, os dois teriam chegado ao Afeganistão, berço da tradição sufista, onde encontraram os conhecimentos e a sabedoria que levaram para a Europa e para a América (Riso, 1994, 1995; Speeth, 1999). Gurdjeff estabeleceu a configuração de três centros de energia ou de inteligência operativos em cada pessoa: a cabeça, o coração e a barriga, cujo 
equilíbrio ou falta de harmonia está na origem da personalidade e do nível de crescimento ou imaturidade da pessoa. O desenvolvimento da personalidade começa quando prevalece na pessoa um desses três centros. Três destas personalidades gravitam em torno do centro da barriga ou instintivo (tipos 8, 9 e 1), três gravitam em torno do centro do coração ou emotivo (tipos 2, 3 e 4) e três gravitam em torno do centro da cabeça ou intelectivo (tipos 5, 6 e 7). Toda pessoa se sente levada a depender de um destes três centros como seu polo de referência.

Por barriga, entranhas ou vísceras entende-se a energia vital, a disposição para a ação como componente dominante. Pertencem a essa categoria as pessoas que são voluntariosas, empreendedoras, impulsivas e dinâmicas; no extremo oposto estão os indivíduos que são amantes de uma vida plácida e tranquila. 0 coração tem como característica dominante a dimensão emocional e o sentimento. Tomam parte dessa categoria as pessoas intuitivas, emotivas, sentimentais, dedicadas ao próximo e com um importante senso estético. A cabeça remete ao predomínio do pensamento no modo de ser da pessoa. Pertencem a esse centro os sujeitos reflexivos, cerebrais, interiormente ricos, mas também dissipados e excêntricos. Cada tipo de personalidade, ao privilegiar inconscientemente um dos centros, apoia-se parcialmente em um segundo centro e reprime um terceiro. Uma das tarefas será desenvolver o centro reprimido, buscando, assim, uma maior integração pessoal.

O eneagrama propõe em torno dessa estrutura de fundo nove tipos de personalidade, três para cada esfera operativa, isto é, os "chefes"(tipo 8), os "mediadores" (tipo 9), os "perfeccionistas" (tipo 1) são centrados na área visceral; os "prestativos" (tipo 2), os "organizadores" (tipo 3) e os "artistas" (tipo 4) gravitam em torno da dimensão emocional; os "observadores" (tipo 5), os "legalistas" (tipo 6) e os "otimistas"(tipo 7) ficam centrados no componente do pensamento. A correlação entre o símbolo do eneagrama e os nove tipos de personalidade foi estabelecida por Oscar Ichazo, que situou exatamente os nove traços principais no diagrama do eneagrama e soube ver as nove fixações do ego, as armadilhas e as ideias dos nove tipos (Rorh \& Ebert, 1994).

Naranjo (1997) adaptou o eneagrama às cate530 gorias psicológicas ocidentais e descobriu as motiva- ções inconscientes e os mecanismos de defesa mais típicos a que recorrem as diversas personalidades quando estão em situação de stress. Riso (1994, 1995) estabeleceu correlações entre o eneagrama e as categorias psiquiátricas, com os conceitos freudianos estruturais e ainda com a tipologia junguiana. O eneagrama sugere que a orientação fundamental de toda personalidade é mais o resultado de dinâmicas inconscientes, que condicionam o comportamento, do que de decisões conscientes e maduras. Cada um dos nove tipos trata de "proteger-se de algo" e evita "enfrentar-se com algo", sendo este "algo" aquilo que cada tipo sente como uma ameaça, acionando a motivação inconsciente formada por atitudes que tendam a evitar o perigo. $\mathrm{Na}$ prática, o eneagrama sugere que somente quando se está consciente da própria motivação inconsciente se corrige a força compulsiva e se pode crescer em plenitude. A motivação inconsciente impulsiona o indivíduo a defender-se daquilo que sente como uma ameaça, identificar-se com aquilo que faz bem, criar uma imagem idealizada de si mesmo, converter-se em escravo da própria personalidade e perder cada vez mais o contato com a própria essência e autenticidade.

A divulgação do eneagrama como teoria da personalidade começou no início da década de 1970, graças à colaboração de jesuítas dos Estados Unidos, que "batizaram" o eneagrama ao torná-lo conhecido dentro das comunidades religiosas e leigas e ao utilizá-lo como meio de acompanhamento espiritual, conhecimento pessoal e dinâmicas comunitárias (Riso, 1994, 1995). O que até então havia sido conhecimento privado transmitido de mestre a discípulo converteu-se em informação abundante por meio de cursos e publicações. O eneagrama experimentou uma enorme difusão ao longo da década de 1980-1990, especialmente no mundo anglo-saxão, caracterizada por uma grande variedade de cursos, pela aplicação deste instrumento aos mais diversos âmbitos da vida e por um esforço crescente que tratou de convalidar esta teoria com a investigação clínica e científica.

O eneagrama é aplicado em empresas por diversas instituições, promovendo programas de desenvolvimento humano em diversas áreas: otimização do trabalho em equipe, liderança e motivação, administração de conflitos e mudanças, negociação estratégica, qualidade de vida e produtividade. É um sistema 
terapêutico que também pode ser entendido no contexto da cultura psicológica descrita por Castel (1987). Há várias de suas características que permitem localizá-lo nesse enquadre: a ênfase no crescimento e desenvolvimento pessoal para indivíduos normais; o fato de sua tipologia não ser baseada na patologia, mas em traços de caráter normais e típicos; o fato de ser transmitido, ensinado e experienciado em grupos de encontro, utilizando diversas técnicas para sua transmissão: livros, apostilas, dinâmicas grupais, análises de filmes, painéis com exposição oral de pessoas que descrevem para o público seu tipo (de modo a permitir a identificação e o diagnóstico pessoal), e grupos avançados que utilizam exercícios corporais para desbloquear os centros energéticos localizados na cabeça, no coração e na barriga.

\section{A programação neurolinguística}

A Programação Neurolinguística (PNL) (Andreas, 1995; Bandler, 1987; Bandler \& Grinder, 1982; Bidot \& Morat, 1997; Knight, 1987, Kluckzny \& Teixeira, 1996; O'Connor, 2003; Seymour \& O'Connor, 1996; Spritzer, 1993; Robbins, 1987; 2001) é um sistema de técnicas, axiomas e crenças que seus praticantes utilizam visando principalmente ao desenvolvimento pessoal. Ela é baseada na ideia de que a mente, o corpo e a linguagem interagem para criar a percepção que cada indivíduo tem do mundo, e que essa percepção pode ser alterada pela aplicação de uma variedade de técnicas. A base de tais técnicas é chamada de"modelagem"e envolve a reprodução cuidadosa dos comportamentos e crenças daqueles que atingiram o sucesso pessoal e profissional.

A PNL foi criada na década de 1970 pelos norte-americanos Bandler e Grinder (1982) para ser um conjunto de modelos e princípios que descrevem a relação entre a mente (neuro) e a linguagem (verbal e não verbal), e como a sua interação pode ser organizada (programação) para afetar a mente, o corpo ou o comportamento do indivíduo. Eles utilizaram sua observação sobre a estrutura da linguagem, associando a ciência da informação e da computação à linguística, e deram origem à PNL. Estudaram o comportamento de pessoas que demonstravam eficiência de desempenho e que alcançaram excelência em suas vidas. Essas observações, baseadas na modelagem de estratégias, resultaram na criação de técnicas que tornariam possível a qualquer pessoa alcançar esses objetivos. A PNL estuda o funcionamento da mente humana, permitindo a descoberta de sua programação e o efeito que isso tem na vida das pessoas. Descreve as formas de aprender, de comunicar-se consigo mesmo e com os outros, bem como adquirir novas habilidades e obter resultados desejados, levando a uma reestruturação e ampliação da percepção do mundo (Bandler, 1987).

A PNL pode ser considerada uma metodologia ou uma tecnologia eclética. Trabalha com a linguagem, mas não é linguística. Descreve sistemas, mas não é cibernética. Estuda o comportamento, mas não é psicologia. Ela aborda temas tais como liderança, gestão, motivação e aprendizagem, mesclando administração, política, comunicação e pedagogia. Trata-se de uma modalidade tecnológica extremamente pragmática, sendo utilizada no mundo empresarial e em psicoterapia. Pode se dizer que a PNL seria um corpo de conhecimentos que pretende desenvolver a excelência na experiência subjetiva e no comportamento objetivo da pessoa, buscando aprimorar sua comunicação para atingir metas de autossuperação. O termo "programação" é utilizado com base em uma analogia computacional para a mente humana: o cérebro seria como um hardware e a mente e os pensamentos seriam como um software, funcionando com a hipótese de que é possível "reprogramar" a própria mente, corrigindo e modificando padrões mentais e programações inadequadas geradas no passado (O'Connor \& Seymour, 1995, p.13)

A PNL não se concentra em sintomas, mas no comportamento normal, e visa à excelência do seu desenvolvimento. Nesse sentido, ela pode ser considerada paraterapêutica e inclusive extraterapêutica. Talvez mais do que para a terapia, a PNL esteja voltada para a aprendizagem de novos modelos de comportamento. Nesse sistema, a aprendizagem pode se realizar de dois modos: a) pela cópia de comportamentos bem sucedidos por meio da técnica da modelagem: o indivíduo faz uma conexão com uma pessoa "modelo" ou uma descrição de pessoa dotada de uma habilidade, comportamento ou estratégia de sucesso; e b) pela inovação, ressignificando ou reestruturando sua experiência: a pessoa procura fazer uma síntese criativa utilizando descrições inusitadas advindas de outras áreas do conhecimento; refaz a percepção, modificando 
os filtros, as crenças e valores provenientes desta percepção. Utiliza analogias e metáforas com o objetivo de modificar o significado da experiência ou para que a estrutura ambiental ou contextual da experiência seja refeita ou, pelo menos, percebida de forma diferente. Essa tecnologia psicológica e pedagógica tem como objetivo a identificação e liberação de habilidades de liderança, a melhoria da eficácia na comunicação e nos relacionamentos, o desenvolvimento e a manutenção de estados de excelência pessoal, em uma perspectiva pessoal, grupal e sistêmica (Robbins, 1987, p.5).

De acordo com O'Connor e Seymour (1995, p.2) a PNL compreende três ideias. "Neuro" indica a ideia fundamental de que todos os comportamentos nascem dos processos neurológicos da visão, audição, olfato, paladar, tato e sensação. O mundo é percebido inicialmente por meio dos cinco sentidos, buscando-se compreender a informação e depois agir. A neurologia humana incluiria não apenas os processos mentais invisíveis, mas também as reações fisiológicas a ideias e acontecimentos. Uns refletem os outros no nível físico; corpo e mente formariam uma unidade inseparável. "Linguística" indicaria que as pessoas utilizam a linguagem para ordenar seus pensamentos e comportamentos para se comunicar com os outros. "Programação" refere-se à maneira como os indivíduos organizam suas ideias e ações a fim de produzir resultados. A PNL trata da estrutura da experiência humana subjetiva e de como as pessoas organizam o que percebem por meio dos seus sentidos; também examina a forma como descrevem isso por meio da linguagem e como agem, intencionalmente ou não, para produzir resultados.

De acordo com as informações do Instituto de Neurolinguística Aplicada (www.pnl.med.br/site/ inap.htm, acessado em 10/07/2007) a PNL seria uma maneira de modelar comportamentos, no sentido de permitir que a pessoa comece a compreender a estrutura da experiência interna, partindo do pressuposto de que a experiência humana é feita de visualização (imagens), experiências auditivas e sensações. Existiriam três siste-

$\simeq \quad$ mas básicos de representação predominantes nas 罚 pessoas: o tipo visual, o auditivo e o cinestésico (Bandler 喜 \& Grinder, 1982). A PNL propõe um modelo capaz de observar como os indivíduos processam neurologicamente as informações e o efeito disso em seu compor-

532 tamento e sentimentos pessoais. Ela visaria estudar a estrutura da experiência subjetiva. Estrutura significa imagens, sons ou diálogo interno e as sensações com que a pessoa cria suas experiências internas e influencia seu comportamento externo. A ideia é de que as pessoas possam ter controle sobre suas vidas, fazendo com que suas experiências subjetivas sejam dirigidas de modo a funcionarem de maneira mais benéfica. A PNL pretende oferecer ferramentas para influenciar processos específicos pelos quais as pessoas criam sua experiência subjetiva.

O desafio da PNL seria capacitar as pessoas para assumirem o controle da sua própria evolução cognitiva e tomar consciência de que suas imagens, vozes e sensações internas, que lhes pertencem e podem ser por elas manipuladas. As pessoas precisariam compreender que o que elas pensam que é o mundo real é apenas o seu modelo de ver a realidade, e modificar sua atitude para uma posição na qual possam dizer "se isto é apenas um modelo, eu prefiro ter aquele outro". 0 importante seria a atitude e a adesão a um novo sistema de crenças adequado: "tudo pode ser conseguido". Quando se tem essa crença, a pessoa é capaz de deixar de lado crenças atuais sobre o que é possível e o que não é, e pode começar a descobrir o que pode ser feito. Não importa que dificuldades encontre, haverá sempre duas opções: ou se pode fazê-lo ou não se pode ainda; assim, pode-se começar a procurar o que é preciso fazer para torná-lo possível. Tão logo se assuma que alguma coisa pode ser realizada, é possível fazer o melhor para encontrar as ferramentas e habilidades para torná-la realidade (Robbins, 1987).

O público alvo da PNL inclui profissionais de saúde, da educação, de recursos humanos, de vendas, executivos, pessoas que desejam crescimento pessoal e todos aqueles que pretendem aperfeiçoar o que já sabem e aprender a fazer aquilo que ainda não sabem. Há uma infinidade de cursos de PNL em diversos níveis atualmente oferecidos no mercado.

A Sociedade Brasileira de PNL explica que ela seria uma atitude frente a um mundo onde as formas de comunicação são cada vez mais complexas e dinâmicas; um modelo que ajudaria a entender melhor como o ser humano pensa, age e se comunica. A partir desse conhecimento, seria possível utilizar melhor o cérebro para alcançar os resultados que se deseja. A PNL oferece autoconhecimento para se desenvolver o 
potencial criativo pessoal. Busca promover uma revolução de hábitos e uma evolução existencial. Aplicando as técnicas e métodos da PNL, seria possível superar limitações, conquistar e manter sucesso pessoal e profissional. A PNL propõe-se a ser um modelo transformador e evolutivo que geraria novos valores, capacidades e comportamentos, e sua aplicação ainda ajudaria a combater os chamados "males do século": stress, depressão, síndrome do pânico e transtorno obsessivo-compulsivo. Também seria útil para lidar com problemas de relacionamento, ansiedade, falta de autoconfiança, baixa autoestima, obesidade e problemas de comportamento e de aprendizado. A PNL seria uma arte e uma técnica para convencer e crescer. Empresas estariam inserindo as ferramentas da PNL em seus programas de qualidade por entender que elas podem ser aplicadas com eficácia como técnicas de persuasão e motivação. A PNL ajudaria no desenvolvimento de carreiras, na formação de equipes, na tomada de decisões e nos conflitos de interesses. Buscaria melhorar a comunicação interna e as negociações externas, pois ensina a influenciar as pessoas utilizando a linguagem.

A PNL é um sistema terapêutico prescritivo que tem semelhanças com o eneagrama ao produzir tipos humanos caracterológicos e procurar lidar com essas figuras imaginárias visando à modelagem do pensamento, do sentimento e do comportamento individual, na busca do desenvolvimento e aprimoramento pessoal. Os chavões da cultura psicológica ressoam no discurso da PNL, que se revela um bom exemplar das possibilidades da psicologização no mundo do trabalho, configurando uma modalidade terapêutica bastante alinhada com os interesses do mercado globalizado. Na PNL pode-se observar claramente o marketing elevado à categoria de prática psicológica.

\section{Algumas apreciações críticas às novas tecnologias psicológicas}

Foucault (1999, p.253) afirma que um dos desafios políticos globais da atualidade estaria no avanço dos "dispositivos de normalização e em toda extensão dos efeitos de poder que eles trazem, através da colocação de novas objetividades." Esses dispositivos de normalização teriam na prisão sua figura concreta, mas haveria um processo de expansão das funções de vigilância, punição e normalização por todo o tecido social: a medicina, a psicologia, a educação, a assistência social, o direito e o judiciário estariam assumindo poderes cada vez maiores de controle e de sanção. É possível verificar no desenvolvimento da cultura psicológica a comprovação do seu diagnóstico. A hermenêutica das ciências humanas tem como horizonte uma normalização terapêutica crescente. Elas promovem uma análise da interioridade psicológica que seria portadora da verdade do sujeito e que se alcança por meio das palavras, do discurso sobre si. Pensa-se a subjetividade como uma construção histórica (Foucault, 1982, 1984, 1985, 1995, 1999, 2004) e entende-se a psicologia e suas práticas emergentes como dispositivos de subjetivação.

Como se produzir como sujeito ético fora dos regimes teológicos e científicos? Como inventar outros modos de existir? Foucault propõe o paradigma ético-estético-político: construir uma vida filosófica, por meio do trabalho do pensamento (trabalho sobre si, apropriando-se do sistema de regras que constitui o homem e imprimindo-lhe um novo sentido). Às técnicas de extração da verdade ele opõe uma ética da busca e da produção da verdade: encontra nos gregos da antiguidade uma atitude autenticamente libertadora. A "estética da existência" apoia-se sobre um potencial de resistência do sujeito a um poder jamais erradicável e promete uma coragem da verdade construída sem confissão nem justificação. A verdade consiste, nesse caso, em uma afirmação de si.

Superando a alienação da confissão, o sujeito pode aprender a reivindicar-se como tal. Lutando contra as formas de objetivação, normatização disciplinar e subjetivação hegemônicas de produção da subjetividade contemporânea, pode superar o esmagamento provocado por uma imagem de si imposta pelo outro. A ética da coragem da verdade e a estética da existência tornam-se um momento de libertação: o sujeito pode enunciar uma verdade sobre si sem culpabilidade nem inocência, entretendo uma relação verdadeira consigo mesmo. Subjetivar-se significa então transformar a confissão em produção e exercício de si mesmo, escolhendo uma maneira de ser a partir de sua própria transformação. Esse enfrentamento de toda dominação é político no seu mais alto grau: tarefa de produzir-se 
singularmente, desprendendo-se do que os outros impõem que se seja.

Provavelmente um certo desenvolvimento histórico da psicologia social (Lane \& Codo, 1984) e da psicologia comunitária (Campos, 1998; Ferreira Neto, 2004; Góis, 1993) pode ser pensado no contexto da expansão da cultura psicológica. Sua rigorosa descrição por Castel (1987) parece encontrar verificação na atualidade brasileira, a partir de alguns exemplos aqui analisados. Essa cultura psicológica seria um dos indicadores de que se está caminhando para uma sociedade de controle, baseada na programação positiva dos seres humanos, superando a sociedade disciplinar que se fundava na vigilância e no adestramento dos corpos (Silva, 2005). A vigilância torna-se desnecessária, pois indivíduos uniformes seguem prescrições coletivas e a modulação homogênea dos comportamentos programados torna mais econômica a gestão.

Diferentemente de Casella (2004) e Silva (2002), no campo da psicologia, há diversas propostas de trabalho e intervenção mais críticas em outras áreas: a perspectiva sócio-histórica dialética (Abrantes, Silva \& Martins, 2005 ; Bock, Gonçalves \& Furtado, 2002; Costa-Rosa, 2000), as diversas abordagens do institucionalismo (Altoé, 2004; Baremblitt, 1998; Barus-Michel, 2004; Benelli, 2004), além das análises genealógicas (Ferreira Neto, 2004; Foucault, 1999; Silva, 2005). Entende-se que as implicações éticas e políticas são importantes na atuação dos profissionais da psicologia porque suas práticas são dispositivos de produção de subjetividade.

\section{Considerações Finais}

Aparentemente a psicologia como ciência humana parece estar superando a mera função de mistificar as contradições das relações sociais, dirigindo-se para uma prática mais ampla que visaria ao cultivo do relacional ou à expansão de uma cultura relacional. Essa transformação no campo das práticas psicológicas

$\simeq \quad$ torna-se compreensível considerando a instrumenta罚 lização da própria psicologia no contexto mais amplo 誉 da atual forma de gestão dos riscos na administração de populações problemáticas: cada vez mais punir, educar e tratar se assemelham, superando-se na direção

534 de uma autoprogramação de si.
Entende-se que a filosofia clínica, o eneagrama, a PNL e as "novas objetividades" que propõem mantêm-se em uma ingenuidade completa quanto à real dimensão social constitutiva da subjetividade e da dimensão histórica constitutiva do social, centrados no nível egoico do indivíduo. Desconhecem as relações de poder e saber produtoras de sujeitos no contexto sócio-histórico e não parecem capazes de dar razões para sua própria existência nem para os efeitos que produzem. Eles se configuram como dispositivos psicológicos essencialistas e não históricos. Individualizando e naturalizando o mal-estar do sujeito contemporâneo, têm caráter predominantemente prescritivo. Promovem um achatamento dos planos coletivos, sociais e institucionais da realidade histórica dos seres humanos, que são reduzidos a um presente raso e imediato. Escamoteando a dimensão da sexualidade e das relações de poder, permanecem no plano emocional e relacional da normalidade asséptica e cotidiana. O corpo é tematizado apenas enquanto uma máquina energética que precisa ser aperfeiçoada visando a um funcionamento equilibrado.

Essas novas tecnologias terapêuticas têm como base o homem individual e livre, independente dos demais, autônomo e autocentrado. Carecem de uma reflexão crítica sobre seus limites e a incidência das dimensões sociais e históricas em suas práticas. Situam-se em uma extraterritorialidade social, temporal e espacial, partindo de uma noção do psiquismo humano que pode ser considerada não histórica e universalizadora. A flexibilidade subjetiva que propõem não conduz necessariamente à criação individual e coletiva: essa identidade flexível deve programar-se a si mesma, modulando-se de acordo com as oscilações do mercado, como se fosse ela mesma uma mercadoria.

Por um lado, pensa-se que as novas modalidades terapêuticas emergentes na cultura psicológica brasileira atual encontram suas raízes em uma hermenêutica de si e são promotoras de um sujeito caracterizado por uma individualidade identitária, desconectado do outro. Elas fomentam uma atomização da vida coletiva e prendem o sujeito a uma identidade padronizada e flexível. Operam a partir de modelos subjetivos identitários pela via da semelhança, em uma perspectiva disciplinar, normalizadora e da moral da autenticidade, do dever que os indivíduos têm de serem eles mesmos, atuali- 
zando suas potencialidades e desenvolvendo sua essência interior, mas reconhece-se que elas estariam menos preocupadas com a decifração dos desejos do "eu" profundo e mais dirigidas para o aperfeiçoamento dos prazeres do corpo e da otimização de sua eficácia. Há um deslocamento da individualidade identitária que deveria conhecer a si mesma para uma individualidade flexível, que busca programar-se como uma máquina eficiente.

Seria preciso passar de práticas de decifração e sobrecodificação da individualidade identitária para práticas de invenção de subjetividades em contínuo movimento de diferenciação e singularização, em relações de reciprocidade social. Isso se faz por meio da resistência aos processos de saber/poder hegemônicos produtores de subjetividade serializada. A alternativa ética para a atualidade estaria em um sujeito que, ao contrário de desenvolver sua identidade original, inventa a si mesmo como uma obra de arte, em um empenho constante para desprender-se e diferir de si mesmo. Trata-se de criação e não de autenticidade ou coerência com um "eu" original e verdadeiro. Não se visa à hermenêutica, mas à estética e à ética na produção criativa de si, e não tanto o saber sobre si, mas o cuidado de si. A obsessão com um saber sobre si e com uma verdade interior, ou com uma programação eficiente de si, encontra sua superação em práticas que visam ao cuidado de si.

\section{Referências}

Abrantes, A. A., Silva, N. R., \& Martins, S. T. F. (Orgs.). (2005). Método histórico-social na psicologia social. Petrópolis: Vozes.

Aiub, M. (2004). Para entender filosofia clínica: o apaixonante exercício da filosofia. Rio de Janeiro: Wak.

Aiub, M. (2005). Filosofia clínica: o que é isto? Cadernos: Centro Universitário São Camilo, 11(1), 113-121.

Altoé, S. (Org.). (2004). René Lourau: analista institucional em tempo integral. São Paulo: Hucitec.

Álvarez, R. J. (2001). Distúrbios psicológicos cotidianos. São Paulo: Paulinas.

Andreas, S. (1995). PNL: programação neurolingüística: a nova tecnologia do sucesso (9a. ed.). São Paulo: Campus.

Bandler, R., \& Grinder, J. (1982). Sapos em príncipes: programação neurolingüística. São Paulo: Summus.

Bandler, R. (1987). Usando sua mente: programação neurolingüística. São Paulo: Summus.

Baremblitt, G. F. (1998). Compêndio de análise institucional e outras correntes: teoria e prática. Rio de Janeiro: Record.
Barlach, L. (2005). Oqueéresiliência humana? Uma contribuição para a construção do conceito. Dissertação de mestrado não-publicada, Instituto de Psicologia, Universidade de São Paulo.

Barus-Michel, J. (2004). O sujeito social. Belo Horizonte: PUC-Minas.

Bauman, Z. (1998). O mal-estar da pós-modernidade. Rio de Janeiro: Jorge Zahar.

Benelli, S. J. (2007). A produção da subjetividade na formação contemporânea do clero católico. Tese de doutorado não-publicada, Instituto de Psicologia, Universidade de São Paulo.

Benelli, S. J. (2004). A instituição total como agência de produção de subjetividade na sociedade disciplinar. Estudos de Psicologia (Campinas), 21(3), 237-252.

Benelli, S. J. \& Costa-Rosa, A. (2006). Movimentos religiosos totalitários católicos: efeitos em termos de produção de subjetividade. Estudos de Psicologia (Campinas), 23 (4), 339-358.

Berman, M. (1990). Tudo o que é sólido desmancha no ar: a aventura da modernidade (8a. ed.). São Paulo: Companhia das Letras.

Berne, E. (1974). Os jogos da vida. São Paulo: Arte Nova.

Bidot, N., \& Morat, B. (1997). Neurolingüística e prática do dia-a-dia. São Paulo: Nobel.

Bock, A. M. B., Gonçalves, M. G., \& Furtado, O. (Orgs.) (2002). Psicologia sócio-histórica: uma perspectiva crítica em psicologia. São Paulo: Cortez.

Campos, R. H. F. (Org.). (1998). Psicologia social comunitária. Petrópolis: Vozes.

Casella, M. (2004). Estratégias em psicologia institucional. São Paulo: Loyola.

Castel, R. (1987). A gestão dos riscos: da antipsiquiatria à pós-psicanálise. Rio de Janeiro: Francisco Alves.

Chabreuil, F. (1999). A empresa e seus colaboradores: usando o eneagrama para otimizar recursos. São Paulo: Madras.

Costa-Rosa, A. (2000). O modo psicossocial: um paradigma das práticas substitutivas ao modo asilar. In P. D. C. Amarante (Org.), Ensaios de loucura \& civilização (pp.141-168). Rio de Janeiro: Fiocruz.

Cunha, D. (2005). Crescendo com o eneagrama na espiritualidade. São Paulo: Paulus.

Cunha, D., \& Carlos, L. (1997). Quem é você: construindo a pessoa à luz do eneagrama. São Paulo: Paulus.

Fadiman, J., \& Frager, R. (2005). Teorias da personalidade. São Paulo: Habra.

Fundação Estadual do Bem-Estar do Menor. (2006). Ampliação do atendimento em medida socioeducativa de semiliberdade no Estado de São Paulo. São Paulo: CTSEMI-FEBEM.

Ferreira Neto, J. L. (2004). A formação do psicólogo: clínica, social e mercado. São Paulo: Escuta.

Foucault, M. (1982). A vontade de saber. Rio de Janeiro: Graal.

Foucault, M. (1984). O uso dos prazeres. Rio de Janeiro: Graal. 
Foucault, M. (1985). O cuidado de si. Rio de Janeiro: Graal.

Foucault, M. (1995). O sujeito e o poder. In H. Dreyfus \& P. Rabinow. Michel Foucault, uma trajetória filosófica: para além do estruturalismo e da hermenêutica (pp.231-249). Rio de Janeiro: Forense.

Foucault, M. (1999). Vigiar e punir: nascimento da prisão. Petrópolis: Vozes.

Foucault, M. (2004). A hermenêutica do sujeito. São Paulo: Martins Fontes.

Góis, C. W. L. (1993). Noções de psicologia comunitária. Fortaleza: UFC.

Harris, T. A. (1974). Eu estou OK você está OK. Rio de Janeiro: Arte Nova.

Kluckzny, J., \& Teixeira, E. A. (1996). Programação neurolingüística. São Paulo: Makron.

Knight, S. (1997). A programação neurolingüística e o sucesso nos negócios. São Paulo: Ediouro.

Knight, S. (2001). Introdução à programação neurolingüística. São Paulo: Nobel.

Lane, S. T. M., \& Codo, W. (Orgs.). (1984). Psicologia social: o homem em movimento. São Paulo: Brasiliense.

Lasch, C. (1983). A cultura do narcisismo. Rio de Janeiro: Imago.

Meininger, J. (1985). Osucesso através da análise transacional. São Paulo: Círculo do Livro.

Múrcia, M. A. S. (2000). Auto-ajuda:temperamento controlado, vida transformada. São Paulo: El Shaddai.

Naranjo, C. (1997). Os nove tipos de personalidade: um estudo do caráter humano através do eneagrama. Rio de Janeiro: Objetiva.

O'Connor, J. (2003). PNL. Manual de programação neurolingüiśtica:um guia prático para alcançarresultados. São Paulo: Qualitymark.

Packter, L. (2001). Filosofia clínica: propedêutica (3a. ed.). Florianópolis: Garapuvu.

Palmer, H. (1993). O eneagrama: compreendendo a si mesmo e aos outros em sua vida. São Paulo: Paulinas.

Palmer, H. (1999). O eneagrama no amor e no trabalho: entendendo os seus relacionamentos íntimos e profissionais. São Paulo: Paulinas.

Pangrazzi, A. (1997). El eneagrama: un viaje hacia la libertad. Bilbao: Sal Terrae.
Paterhan, K. (2006). Eneagrama: um caminho para seu sucesso individual e profissional. São Paulo: Madras.

Paulo, M. N. (Org.). (1999). Primeiros passos em filosofia clínica. Porto Alegre: Imprensa Livre.

Paulo, M. N. (2001). Compêndio de filosofia clínica. Porto Alegre: Imprensa Livre.

Pinheiro, D. P. N. (2004). A resiliência em discussão. Psicologia em Estudo, 9 (1), 67-75.

Riso, R. (1994). Comprendiendo el eneagrama. Santiago: Cuatro Vientos.

Riso, R. (1995). Tipos de personalidad: el eneagrama para descubrir-se a si mismo. Santiago: Cuatro Vientos.

Robbins, A. (1987). Poder sem limites: programação neurolingüística. São Paulo: Best Seller.

Rohr, R. (2000). O eneagrama promovendo o discernimento espiritual. São Paulo: Paulinas.

Rohr, R., \& Ebert, A. (1994). O eneagrama: as nove faces da alma. Petrópolis: Vozes.

Salmon, E. (2000). O fantástico eneagrama: reconhecer as diferentes forças que nos animam. Cascais: Pergaminho.

Seymour, J. \& O'Connor, J. (1996). Treinando com a PNL: recursos de programação neurolingüística para administração, instrução e comércio. São Paulo: Summus.

Silva, R. C. (2002). Metodologias participativas para trabalhos de promoção de saúde e cidadania. São Paulo: Vetor.

Silva, R. N. (2005). A invenção da psicologia social. Petrópolis: Vozes.

Speeth, K. R. (1999). O trabalho de Gurdjieff. São Paulo: Cultrix.

Spritzer, N. (1993). Pensamento e mudança: desmistificando a programação neurolingüística. Porto Alegre: L\&PM.

Tavares, J. (2001). A resiliência na sociedade emergente. In J. Tavares (Org.), Resiliência e educação (pp.43-75). São Paulo: Cortez.

Yunes, M. A. M. (2003). Psicologia positiva e resiliência: o foco no indivíduo e na família. Psicologia em Estudo, 8 (Especial), 75-84.

Zuercher, S. (2001). A espiritualidade do eneagrama: da compulsão à contemplação. São Paulo: Paulus.

Recebido em: 24/8/2007

Versão final reapresentada em: 11/2/2008

Aprovado em: 10/3/2008 